\title{
Systematic Review \\ Determinants of Healthcare Use Based on the Andersen Model: A Systematic Review of Longitudinal Studies
}

\author{
André Hajek*(D), Benedikt Kretzler and Hans-Helmut König \\ Hamburg Center for Health Economics, Department of Health Economics and Health Services Research, \\ University Medical Center Hamburg-Eppendorf, 20246 Hamburg, Germany; b.kretzler.ext@uke.de (B.K.); \\ h.koenig@uke.de (H.-H.K.) \\ * Correspondence: a.hajek@uke.de; Tel.: +49-40-7410-52877; Fax: +49-40-7410-40261
}

Citation: Hajek, A.; Kretzler, B.; König, H.-H. Determinants of Healthcare Use Based on the Andersen Model: A Systematic Review of Longitudinal Studies. Healthcare 2021, 9, 1354. https:// doi.org/10.3390/healthcare9101354

Academic Editor: Rocío De Andrés Calle

Received: 7 September 2021

Accepted: 6 October 2021

Published: 12 October 2021

Publisher's Note: MDPI stays neutral with regard to jurisdictional claims in published maps and institutional affiliations.

Copyright: (c) 2021 by the authors. Licensee MDPI, Basel, Switzerland. This article is an open access article distributed under the terms and conditions of the Creative Commons Attribution (CC BY) license (https:/ / creativecommons.org/licenses/by/ $4.0 /)$.
Abstract: The aim was to give an overview of longitudinal observational studies investigating the determinants of healthcare use explicitly using the Andersen model. To this end, three electronic databases (Medline, PsycINFO and CINAHL) were searched (and an additional hand search was performed). Longitudinal observational studies examining the determinants of healthcare use (outpatient physician services and hospital stays) based on the Andersen model were included, whereas disease-specific samples were excluded. Study quality was evaluated. The selection of studies, extraction of data and assessment of the studies were conducted by two reviewers. The following determinants of healthcare use were displayed based on the (extended) Andersen model: predisposing characteristics, enabling resources, need factors and psychosocial factors. In sum, $n=10$ longitudinal studies have been included in our systematic review. The included studies particularly showed a longitudinal association between increased needs and higher healthcare use. Study quality was rather high. However, several studies did not conduct robustness checks or clarify the handling of missing data. In conclusion, this systematic review adds to our current understanding of the factors associated with healthcare use (mainly based on cross-sectional studies). It showed mixed evidence with regard to the association between predisposing characteristics, enabling resources and healthcare use longitudinally. In contrast, increased need factors (in particular, self-rated health and chronic conditions) were almost consistently associated with increased healthcare use. This knowledge may assist in managing healthcare use. Since most of the studies were conducted in North America or Europe, future longitudinal studies from other regions are urgently required.

Keywords: healthcare use; health services research; Andersen; healthcare utilization; predisposing characteristics; enabling resources; need factors; systematic review; longitudinal studies; cohort studies; observational studies

\section{Introduction}

Healthcare use (HCU) mainly includes physician visits (particularly general practitioner (GP) and specialist visits) as well as hospitalization. One landmark theoretical model to study the determinants of HCU is called the Andersen Model [1] with the dimensions of predisposing characteristics (e.g., chronological age or sex), enabling resources (e.g., self-rated access to hospital or household income) and need factors (e.g., number of physical illnesses, mental health or self-rated health). Moreover, recent studies have suggested adding psychosocial factors such as loneliness and personality factors such as conscientiousness to the Andersen model [2].

To date, various cross-sectional studies-based on the Andersen model-exist to investigate the factors associated with HCU (e.g., [3,4]). A previous systematic review published almost ten years ago (i.e., in the year 2012) systematically synthesized studies analyzing the determinants of HCU based on the Andersen model [5]. While mixed determinants were included, an overall association between increased need factors and increased HCU has 
been found in a previous review [5]. However, in the past few years, several longitudinal studies have been published (for example, [6])—often demonstrating that increases in needs are associated with increases in HCU. Nevertheless, thus far, a systematic review systematically synthesizing longitudinal studies analyzing the determinants of HCUexplicitly using the Andersen model-is lacking. Consequently, the aim of this review was to close this gap in knowledge. In total, this knowledge may be beneficial to manage HCU and can help to avoid over-, under- and misuse (e.g., if particularly predisposing factors such as country of origin or sex are associated with HCU). Contrary, if need factors are exclusively associated with HCU based on a longitudinal approach, this could indicate that health services are used only if medically indicated.

Moreover, a systematic review solely based on longitudinal studies in this research area is required since longitudinal studies can assist in clarifying the directionality between the factors. Additionally, and in contrast to results based on cross-sectional studies, results based on longitudinal studies can produce consistent estimates when certain panel regression models were applied.

It should be noted that other domains of HCU exist, such as check-ups, dental services or mental HCU. Nevertheless, we concentrate on outpatient physician visits and hospitalization in this current systematic review due to homogeneity in the dependent variables. Furthermore, these outcome measures differ in their correlates.

\section{Material and Methods}

Our systematic review was performed in accordance with the Preferred Reporting Items for Systematic Reviews and Meta-Analysis guidelines [7]. Moreover, it is registered with the International Prospective Register of Systematic Reviews (PROSPERO, registration number: CRD42020193198). Additionally, a study protocol for our systematic review has recently been published [8]. All steps (study selection, data extracting and quality assessment) were independently conducted by two reviewers. When opinions differed between the reviewers, discussions were used to resolve it. A third party (H.H.K.) was used (if required).

\subsection{Search Strategy and Eligibility Criteria}

In May and June 2021, a systematic literature search was conducted (Medline, PsycINFO and CINAHL). In Table 1, the search query for Medline is presented.

Inclusion criteria were as follows: (i) longitudinal observational studies examining the determinants of HCU in terms of outpatient physician services (such as GP visits or specialist visits in total) or hospitalization, (ii) studies explicitly using the Andersen model, (iii) measurement of important variables with suitable tools, (iv) studies in German or English language and (v) studies published in peer-reviewed, scientific journals. In contrast, exclusion criteria were (i) studies exclusively based on samples with a specific disorder (e.g., individuals with mental disorders) and (ii) studies solely examining single medical specialties (other than GP visits) such as ophthalmologist (visits).

No restrictions were made regarding location or time of the studies. A pretest was conducted prior to final eligibility criteria (using a sample of 100 titles/abstracts). However, our eligibility criteria did not change. 
Table 1. Search strategy for Medline.

\begin{tabular}{cc}
\hline$\# 1$ & Health care \\
\hline$\# 2$ & Health service $^{*}$ \\
\hline$\# 3$ & \#1 OR \#2 \\
\hline$\# 4$ & Use \\
\hline$\# 5$ & Utili ${ }^{*}$ \\
\hline$\# 6$ & \#3 AND \#6 \\
\hline$\# 7$ & GP visits \\
\hline$\# 8$ & Hospital admission \\
\hline$\# 9$ & Hospitalization \\
\hline$\# 10$ & Specialist visits \\
\hline$\# 11$ & Doctor visits \\
\hline$\# 12$ & Physician visits \\
\hline$\# 13$ & General Practitioner visits \\
\hline$\# 14$ & Andersen model
\end{tabular}

Note: The asterisk $\left.{ }^{*}\right)$ is a truncation symbol. The number sign (\#) refers to the search order.

\subsection{Study Selection}

The identified studies were imported into EndNote X8 (Clarivate Analytics, Philadelphia, PA, USA). Studies were evaluated for inclusion/exclusion based on a two-step approach starting with a title/abstract screening and a full-text screening afterwards. Furthermore, a hand search was conducted.

\subsection{Data Extraction and Analysis}

One reviewer (B.K.) performed extraction of the data and a second reviewer (A.H.) checked it. If required, the study authors were contacted for clarification. Data on study design, measurement of HCU, characteristics of the sample, size of the sample and key findings were extracted. The key findings are displayed based on the Andersen model.

\subsection{Quality Assessment}

As yet, there is no consensus regarding a quality assessment tool for HCU studies. In this study, we used a tool developed by Stuhldreher et al. [9] and refined by Hohls et al. [10]. For further details, please see Table 2 in a study conducted by Hajek et al. [11]. 
Table 2. Key characteristics and main findings of studies included in the final synthesis $(n=10)$.

\begin{tabular}{|c|c|c|c|c|c|c|c|c|c|}
\hline $\begin{array}{l}\text { First } \\
\text { Author }\end{array}$ & Country & $\begin{array}{l}\text { Assessment of } \\
\text { Health Care } \\
\text { Utilization }\end{array}$ & Waves and Duration & Sample Description & $\begin{array}{l}\text { Sample Size; } \\
\text { Age; } \\
\text { Females in Total Sample }\end{array}$ & $\begin{array}{l}\text { Results: } \\
\text { Predisposing Factors }\end{array}$ & $\begin{array}{l}\text { Results: } \\
\text { Enabling Factors }\end{array}$ & $\begin{array}{l}\text { Results: } \\
\text { Need Factors }\end{array}$ & $\begin{array}{l}\text { Results: } \\
\text { Psychosocial } \\
\text { Factors }\end{array}$ \\
\hline $\begin{array}{l}\text { Al Snih } \\
\text { (2006) [12] }\end{array}$ & United States & $\begin{array}{l}\text { Number of } \\
\text { physician visits and } \\
\text { hospitalizations } \\
\text { during the last } \\
\text { twelve months }\end{array}$ & $\begin{array}{l}\text { Two waves from } \\
1993 \text { to } 1996\end{array}$ & $\begin{array}{l}\text { Hispanic Established } \\
\text { Population from the } \\
\text { Epidemiological } \\
\text { Study of the Elderly }\end{array}$ & $\begin{array}{l}n=1987 \\
\text { M: } 72.6 \\
\text { SD: } 6.1 \\
\geq 65 \\
59.5 \%\end{array}$ & $\begin{array}{l}\text { According to multiple } \\
\text { regression analysis, } \\
\text { age }(\beta=0.04, p<0.05) \\
\text { and being female }(\beta= \\
0.97, p<0.0001) \text { were } \\
\text { related to physician } \\
\text { visits. Marital status, } \\
\text { education and nativity } \\
\text { remained insignificant. }\end{array}$ & $\begin{array}{l}\text { Receiving Medicare } \\
\text { only }(B=0.89, p<0.05) \\
\text { or Medicare and } \\
\text { Medicaid ( }(=1.33, p< \\
0.001) \text { was significantly } \\
\text { associated with } \\
\text { physician visits. } \\
\text { Number of children, } \\
\text { financial strain and } \\
\text { having a usual source } \\
\text { of care were not } \\
\text { significant predictors. }\end{array}$ & 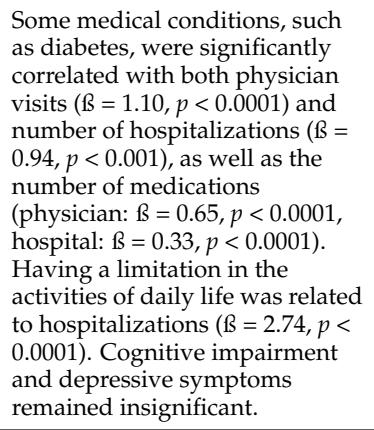 & Not applicable \\
\hline $\begin{array}{l}\text { Clay (2011) } \\
\text { [13] }\end{array}$ & United States & $\begin{array}{l}\text { Time since the last } \\
\text { nonsurgical } \\
\text { overnight hospital } \\
\text { admission }\end{array}$ & $\begin{array}{l}\text { Nine waves from } \\
1999 \text { to } 2005\end{array}$ & $\begin{array}{l}\text { Community- } \\
\text { dwelling adults aged } \\
65 \text { years and older }\end{array}$ & $\begin{array}{l}n=942 \\
\text { M: } 75.3 \\
\text { SD: } 6.7 \\
65-106 \\
50.7 \%\end{array}$ & $\begin{array}{l}\text { Univariate Cox } \\
\text { proportional hazard } \\
\text { ratios show that race } \\
\text { (African American vs. } \\
\text { Caucasian: OR: } 0.74, \\
\text { 95\% CI: } 0.59-0.93 \text { ) and } \\
\text { age (OR: } 1.03,95 \% \text { CI: } \\
\text { 1.01-1.05) were } \\
\text { significantly related to } \\
\text { the outcome variable. } \\
\text { Gender, marital status, } \\
\text { education and } \\
\text { residence were not. }\end{array}$ & $\begin{array}{l}\text { Social support (OR: } \\
\text { 1.04, 95\% CI: } 1.00-1.09) \\
\text { and perceived } \\
\text { discrimination (OR: } \\
0.88,95 \% \text { CI: } 0.77-0.99) \\
\text { were significantly } \\
\text { correlated with the } \\
\text { time gap. Mental state } \\
\text { and private insurance } \\
\text { were not. }\end{array}$ & $\begin{array}{l}\text { Physical health (OR: } 0.97,95 \% \\
\text { CI: } 0.96-0.98 \text { ), limitations among } \\
\text { activities of daily life (OR: } 1.19, \\
\text { 95\% CI: } 1.10-1.29 \text { ) and physical } \\
\text { performance (OR: } 0.91,95 \% \text { CI: } \\
0.89-0.95 \text { ) were significantly } \\
\text { associated with the time since } \\
\text { the last nonsurgical overnight } \\
\text { hospital admission.Depressive } \\
\text { symptoms (OR: } 1.09,95 \% \text { CI: } \\
\text { 1.04-1.14), anxiety (OR: } 0.96 \text {, } \\
\text { 95\% CI: 0.93-0.98) and mental } \\
\text { health (OR: } 0.98,95 \% \text { CI: } \\
\text { 0.97-0.99) were significantly } \\
\text { correlated with the time gap. }\end{array}$ & Not applicable \\
\hline $\begin{array}{l}\text { Gabet } \\
\text { (2019) [14] }\end{array}$ & Canada & $\begin{array}{l}\text { Having used an } \\
\text { emergency } \\
\text { department during } \\
\text { the last twelve } \\
\text { months }\end{array}$ & $\begin{array}{l}\text { Two waves from } \\
2017 \text { to } 2018\end{array}$ & $\begin{array}{l}\text { Homeless people } \\
\text { from Montreal }\end{array}$ & $\begin{array}{l}n=270 \\
18-39: 5.2 \% \\
40-49: 38.2 \% \\
\geq 50: 56.6 \% \\
42.2 \%\end{array}$ & Not applicable & $\begin{array}{l}\text { According to multiple } \\
\text { logistic regression, } \\
\text { specialized ambulatory } \\
\text { service use (OR: } 1.74, \\
95 \% \text { CI: } 1.00-3.01 \text { ) and } \\
\text { stigma (OR: } 0.70,95 \% \\
\text { CI: } 0.56-0.89) \text { were } \\
\text { significantly associated } \\
\text { with emergency } \\
\text { department use. }\end{array}$ & $\begin{array}{l}\text { Substance use disorders (OR: } \\
1.70,95 \% \text { CI: } 1.01-2.87 \text { ) and } \\
\text { perceived physical health (OR: } \\
0.75,95 \% \text { CI: } 0.58-0.98 \text { ) were } \\
\text { significantly correlated with } \\
\text { emergency department } \\
\text { utilization. }\end{array}$ & Not applicable \\
\hline
\end{tabular}


Table 2. Cont.

\begin{tabular}{|c|c|c|c|c|c|c|c|c|c|}
\hline $\begin{array}{l}\text { First } \\
\text { Author }\end{array}$ & Country & $\begin{array}{l}\text { Assessment of } \\
\text { Health Care } \\
\text { Utilization }\end{array}$ & Waves and Duration & Sample Description & $\begin{array}{l}\text { Sample Size; } \\
\text { Age; } \\
\text { Females in Total Sample }\end{array}$ & $\begin{array}{l}\text { Results: } \\
\text { Predisposing Factors }\end{array}$ & $\begin{array}{l}\text { Results: } \\
\text { Enabling Factors }\end{array}$ & $\begin{array}{l}\text { Results: } \\
\text { Need Factors }\end{array}$ & $\begin{array}{l}\text { Results: } \\
\text { Psychosocial } \\
\text { Factors } \\
\end{array}$ \\
\hline $\begin{array}{l}\text { Hadwiger } \\
\text { (2019) [15] }\end{array}$ & Germany & $\begin{array}{l}\text { Six or more } \\
\text { physician } \\
\text { consultations during } \\
\text { the last three months }\end{array}$ & $\begin{array}{l}\text { Seven waves from } \\
2002 \text { to } 2014\end{array}$ & $\begin{array}{l}\text { German Socio- } \\
\text { Economic-Panel }\end{array}$ & $\begin{array}{l}n=28,574 \\
\text { M: } 53.6 \\
\text { SD: } 16.7 \\
17-102 \\
55.6 \%\end{array}$ & $\begin{array}{l}\text { The regression results } \\
\text { show that being a } \\
\text { frequent attender was } \\
\text { significantly associated } \\
\text { with lower age (OR: } \\
0.95,95 \% \text { CI: } 0.94-0.96) \text {, } \\
\text { having a partner (OR: } \\
1.22,95 \% \text { CI: } 1.07-1.41) \\
\text { and non-working (OR: } \\
1.35,95 \% \text { CI: } \\
1.22-1.50 \text { ). }\end{array}$ & $\begin{array}{l}\text { Logarithmized } \\
\text { equivalent income and } \\
\text { having a private health } \\
\text { insurance remained } \\
\text { insignificant. }\end{array}$ & $\begin{array}{l}\text { Frequent attenders were likely } \\
\text { to have a lower physical health } \\
\text { (reversed OR: } 1.11,95 \% \text { CI: } \\
1.11-1.12 \text { ) and mental health } \\
\text { composite score (reversed OR: } \\
1.05,95 \% \text { CI: } 1.05-1.05 \text { ). }\end{array}$ & Not applicable \\
\hline $\begin{array}{l}\text { Hajek } \\
\text { (2017a) [19] }\end{array}$ & Germany & $\begin{array}{l}\text { Number of } \\
\text { physician visits } \\
\text { during the last three } \\
\text { months }\end{array}$ & $\begin{array}{l}\text { Two waves from } \\
2005 \text { to } 2010\end{array}$ & $\begin{array}{l}\text { German Socio- } \\
\text { Economic-Panel }\end{array}$ & $\begin{array}{l}n=11,310 \\
\text { M: } 51.8 \\
\text { SD: } 16.4 \\
17-100 \\
55.4 \%\end{array}$ & $\begin{array}{l}\text { According to Poisson } \\
\text { regression, age, marital } \\
\text { status, education and } \\
\text { employment status } \\
\text { were not significantly } \\
\text { related to the number } \\
\text { of physician visits. }\end{array}$ & $\begin{array}{l}\text { The logarithmized } \\
\text { equivalent income } \\
\text { remained insignificant. }\end{array}$ & $\begin{array}{l}\text { The number of physician visits } \\
\text { was positively associated with } \\
\text { decreased self-rated health }(B= \\
0.40, p<0.001 \text { ) and being } \\
\text { severely disabled }(B=0.18, p< \\
0.001) \text {. }\end{array}$ & $\begin{array}{l}\text { An external } \\
\text { locus of control } \\
\text { was positively } \\
\text { correlated with } \\
\text { higher levels of } \\
\text { physician visits } \\
(ß=0.00, p< \\
0.05) \text {. Internal } \\
\text { locus of control } \\
\text { was not } \\
\text { significant. } \\
\end{array}$ \\
\hline $\begin{array}{l}\text { Hajek } \\
\text { (2017b) [16] }\end{array}$ & Germany & $\begin{array}{l}\text { Number of GP visits, } \\
\text { specialist visits and } \\
\text { having had a } \\
\text { hospital stay during } \\
\text { the last twelve } \\
\text { months }\end{array}$ & $\begin{array}{l}\text { Two waves from } \\
2008 \text { to } 2011\end{array}$ & $\begin{array}{l}\text { German Ageing } \\
\text { Survey }\end{array}$ & $\begin{array}{l}n=1372 \\
\text { M: } 64.3 \\
\text { SD: } 11.2 \\
40-95 \\
52.2 \%\end{array}$ & $\begin{array}{l}\text { Regarding fixed-effects } \\
\text { regression, being } \\
\text { retired ( }(=0.17, p< \\
0.05) \text { or not employed } \\
(\beta=0.18, p<0.05) \text { was } \\
\text { related to more } \\
\text { physician visits. A } \\
\text { higher age was } \\
\text { associated with a } \\
\text { having a hospital stay } \\
\text { (OR: } 0.91,95 \% \text { CI: } \\
\text { 0.84-0.98), as well as } \\
\text { not being employed } \\
\text { (OR: } 2.37,95 \% \text { CI: } \\
1.01-5.56) \text {. Marital } \\
\text { status remained } \\
\text { insignificant. }\end{array}$ & $\begin{array}{l}\text { Logarithmized } \\
\text { equivalent income and } \\
\text { self-rated accessibility } \\
\text { of doctors were not } \\
\text { significant predictors. }\end{array}$ & $\begin{array}{l}\text { Self-rated health was associated } \\
\text { with all GP visits }(B=0.11, p< \\
0.001) \text {, specialist visits }(B=0.20, \\
p<0.001) \text { and a hospital stay } \\
\text { (OR: } 1.77 \text {, OR: 1.34-2.32). The } \\
\text { number of chronic diseases was } \\
\text { related to more GP visits }(B= \\
0.04, p<0.01) \text { and specialist } \\
\text { visite }(B=0.06, p<0.01) \text {. } \\
\text { Overweight }(B=-0.16, p<0.05) \\
\text { and obesity }(B=0.24, p<0.05) \\
\text { were related to a lower number } \\
\text { of specialist visits. Underweight, } \\
\text { currently smoking and physical } \\
\text { activity remained insignificant. }\end{array}$ & Not applicable \\
\hline
\end{tabular}


Table 2. Cont.

\begin{tabular}{|c|c|c|c|c|c|c|c|c|c|}
\hline $\begin{array}{l}\text { First } \\
\text { Author }\end{array}$ & Country & $\begin{array}{l}\text { Assessment of } \\
\text { Health Care } \\
\text { Utilization }\end{array}$ & Waves and Duration & Sample Description & $\begin{array}{l}\text { Sample Size; } \\
\text { Age; } \\
\text { Females in Total Sample }\end{array}$ & $\begin{array}{l}\text { Results: } \\
\text { Predisposing Factors }\end{array}$ & $\begin{array}{l}\text { Results: } \\
\text { Enabling Factors }\end{array}$ & $\begin{array}{l}\text { Results: } \\
\text { Need Factors }\end{array}$ & $\begin{array}{l}\text { Results: } \\
\text { Psychosocial } \\
\text { Factors } \\
\end{array}$ \\
\hline $\begin{array}{l}\text { Hajek } \\
\text { (2018) [18] }\end{array}$ & Germany & $\begin{array}{l}\text { Number of GP visits } \\
\text { and specialist visits } \\
\text { during the last three } \\
\text { months }\end{array}$ & $\begin{array}{l}\text { Two waves during a } \\
\text { ten-month period }\end{array}$ & AgeQualiDe & $\begin{array}{l}n=861 \\
\text { M: } 89.0 \\
\text { SD: } 2.9 \\
85-100 \\
69.0 \%\end{array}$ & $\begin{array}{l}\text { Poisson fixed-effects } \\
\text { regression did not } \\
\text { detect age or marital } \\
\text { status as significant } \\
\text { correlates. }\end{array}$ & $\begin{array}{l}\text { Social network was not } \\
\text { significantly correlated } \\
\text { with GP visits. }\end{array}$ & $\begin{array}{l}\text { Increasing cognitive impairment } \\
(\beta=0.17, p<0.05) \text { and } \\
\text { increasing depressive symptoms } \\
(\beta=0.04, p<0.1) \text { were } \\
\text { significantly related to GP visits, } \\
\text { while functional impairment } \\
\text { and the number of chronic } \\
\text { conditions were not. }\end{array}$ & Not applicable \\
\hline $\begin{array}{l}\text { Hajek } \\
(2020)[17]\end{array}$ & Germany & $\begin{array}{l}\text { Having had a } \\
\text { hospital visit during } \\
\text { the last six months }\end{array}$ & $\begin{array}{l}\text { Two waves during a } \\
\text { ten-month period }\end{array}$ & AgeQualiDe & $\begin{array}{l}n=861 \\
\text { M: } 89.0 \\
\text { SD: } 2.9 \\
85-100 \\
69.0 \%\end{array}$ & $\begin{array}{l}\text { According to } \\
\text { random-effects } \\
\text { regression, age, sex } \\
\text { and marital status } \\
\text { were not associated } \\
\text { with hospitalization. }\end{array}$ & $\begin{array}{l}\text { A higher social } \\
\text { network (OR: } 1.15,95 \% \\
\text { CI: } 1.06-1.25 \text { ) was } \\
\text { associated with a } \\
\text { higher likelihood of } \\
\text { hospitalization. } \\
\text { Education remained } \\
\text { insignificant. }\end{array}$ & $\begin{array}{l}\text { A higher number of chronic } \\
\text { conditions (OR: } 1.06,95 \% \text { CI: } \\
1.02-1.10 \text { ) and increased } \\
\text { depressive symptoms (OR: } 1.11 \text {, } \\
95 \% \text { CI: } 1.05-1.18 \text { ) } \\
\text { were significantly related to } \\
\text { hospitalization. } \\
\text { Moreover, the interaction } \\
\text { between social network and } \\
\text { functioning (OR: } 0.98,95 \% \text { CI: } \\
\text { 0.97-0.99) was associated with } \\
\text { hospitalization.Cognitive } \\
\text { impairment and functioning } \\
\text { were not. }\end{array}$ & Not applicable \\
\hline $\begin{array}{l}\text { Stein }(2000) \\
{[21]}\end{array}$ & United States & $\begin{array}{l}\text { Having had a } \\
\text { hospital visit or an } \\
\text { outpatient visit } \\
\text { during the last } \\
\text { twelve months }\end{array}$ & $\begin{array}{l}\text { Two waves from } \\
1990 \text { to } 1991\end{array}$ & $\begin{array}{l}\text { Homeless people } \\
\text { living in Los } \\
\text { Angeles County }\end{array}$ & $\begin{array}{l}n=363 \\
\text { M: } 38.1 \\
18-70 \\
30.0 \%\end{array}$ & $\begin{array}{l}\text { According to the } \\
\text { pathway model, } \\
\text { hospitalizations were } \\
\text { significantly related to } \\
\text { education }(B=-0.10, p \\
<0.05), \text { being African } \\
\text { American ( }(B=0.09, p< \\
0.05) \text { and drug use }(B= \\
0.13, p<0.05) \text {. } \\
\text { Ambulatory office } \\
\text { visits were associated } \\
\text { with alcohol problems } \\
(B=-0.10, p<0.05) \\
\text { and drug use }(B=0.18, \\
p<0.01) \text {. Poor housing } \\
\text { remained insignificant. }\end{array}$ & $\begin{array}{l}\text { Having a place to go } \\
\text { for health care was } \\
\text { related to increased } \\
\text { levels of ambulatory } \\
\text { office visits }(B=0.32, p \\
<0.001) \text { and } \\
\text { community support ( } \beta \\
=0.10, p<0.05) \text {. } \\
\text { Hospitalizations were } \\
\text { related to community } \\
\text { support }(B=0.10, p< \\
0.05) \text { and barriers }(\beta= \\
0.17, p<0.001) \text {. Health } \\
\text { insurance and social } \\
\text { support were not } \\
\text { significant predictors. }\end{array}$ & $\begin{array}{l}\text { Having a poor health was } \\
\text { related both to ambulatory office } \\
\text { visits ( }(=0.09, p<0.05) \text { and } \\
\text { hospitalizations }(B=0.12, p< \\
0.05) \text {. } \\
\text { Psychotics and depression } \\
\text { remained insignificant. }\end{array}$ & Not applicable \\
\hline
\end{tabular}




\section{Results}

\subsection{Overview of Included Studies}

The study selection process is displayed in Figure 1.
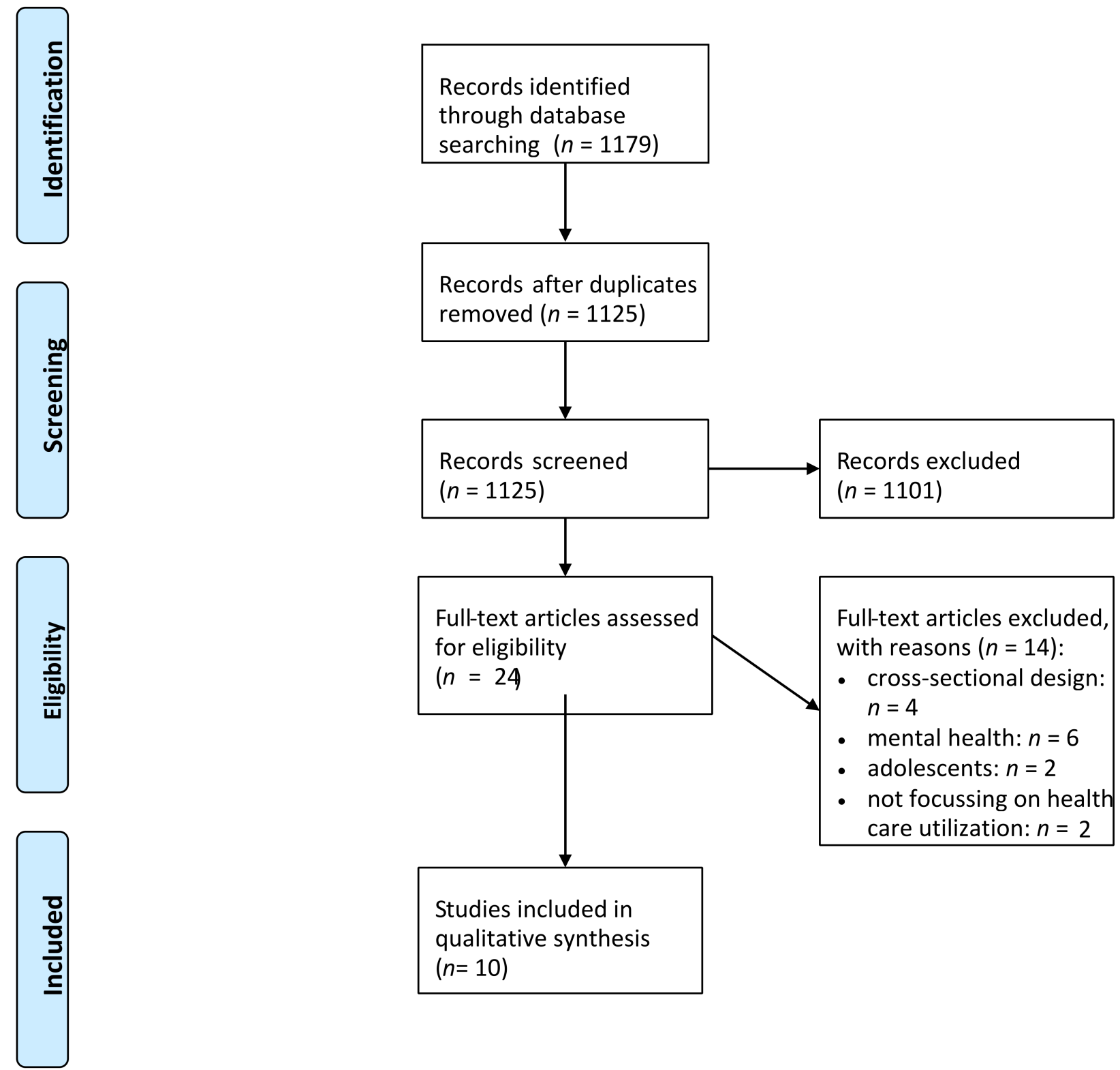

Figure 1. Flow chart. PRISMA 2009 Flow Diagram.

In total, $n=10$ studies are included in our review [12-21]. Important findings of the studies are shown in Table 2 (if shown, adjusted results are given in Table 2). Data came from North America ( $n=$ four, with three studies from the United States and one study from Canada), Europe ( $n=$ five, all from Germany) and Asia ( $n=$ one, South Korea). The observation period ranged from ten months to twelve years. The number of waves used ranged from two to nine waves.

While two studies only examined the frequency of physician visits, three studies exclusively examined the likelihood of hospitalization. Moreover, five studies used different outcomes (such as the frequency of GP as well as specialist visits and hospitalization). All studies investigated the outpatient physician visits/hospitalization in the last three to twelve months. 
One study used a Cox proportional hazards model [13]. Furthermore, all five German studies used specifically designed panel regression models [15-19]. Three studies used a static set of baseline characteristics (such as sex) to predict subsequent outcomes [12,14,21] or used pooled models [20]—and, therefore, do not fully exploit the longitudinal data structure [22]. Furthermore, they may have produced inconsistent estimates due to unobserved heterogeneity [22].

Most of the studies focused on middle-aged or older individuals. The sample size ranged from 270 to 28,574 individuals and the proportion of women ranged from 30 to $69 \%$. Additional details are given in Table 2.

We will display our key findings in the following upcoming sections according to the extended [2] Andersen model for reasons of clarity and readability: predisposing characteristics, enabling resources, need factors and psychosocial factors.

\subsection{Predisposing Characteristics}

In total, $n=$ nine studies examined the association between predisposing characteristics and HCU longitudinally.

With regard to age, eight studies examined the association between age and HCU. Three studies did not find an association between these factors [17-19]. Moreover, while three studies found a positive association between these factors $[12,13,16]$, two studies found negative associations $[15,20]$.

With regard to sex, four studies examined the association between sex and HCU. While two studies found an association between being female and higher HCU [12,20], two other studies did not find a significant association between sex and HCU [13,17].

With regard to educational level, five studies examined an association between educational level and HCU $[12,13,17,19,20]$. However, none of the studies found a significant association between these factors.

With regard to marital status, eight studies investigated the association between marital status and HCU. While six studies did not identify an association between these factors [12,13,16-19], two studies found an association between being married or having a partner and increased HCU $[15,20]$.

Other predisposing characteristics were only included occasionally. For example, three studies examined an association between employment status and HCU. While two studies found an association between unemployment and higher HCU [15,16], one study did not determine a significant association between these factors [19]. Moreover, three studies examined the association between race and HCU. Two studies did not identify an association between race and HCU $[12,13]$, whereas one study showed that being African American (compared to others) was associated with a higher likelihood of hospitalization [21].

\subsection{Enabling Resources}

In total, all the $n=10$ studies examined the association between enabling resources and HCU longitudinally.

With regard to income, four studies examined the association between income and HCU. None of these studies found a significant association [15,16,19,20]. Analogously, health insurance was not significantly associated with HCU in the three studies that examined such an association $[13,15,21]$. While the German study compared statutory health insurance and private health insurance with regard to HCU [15], one study conducted in the United States compared individuals who did not have private insurance in addition to Medicare and individuals with private insurance among older African American and Caucasian Medicare Beneficiaries [13], and another study compared homeless individuals with health insurance with homeless individuals without health insurance in the United States [21].

With regard to social support/social network, two out of the four studies did not find an association between social support/social network and HCU [18,21]. In contrast, one 
study found an association between higher social network and an increased likelihood of hospitalization among the oldest old [17]. Similar findings were made by Clay et al. [13].

\subsection{Need Factors}

In total, all the $n=10$ studies examined the association between need factors and HCU longitudinally. In general, all the studies found an association between higher needs and higher HCU. In particular, strong associations were found between chronic conditions as well as low self-rated health and increased HCU [12,16,17,19,21]. However, two studies also found that disability/functional impairment was not associated with increased HCU $[18,20]$.

With regard to mental health, three studies also found an association between decreased mental health and increased HCU $[15,17,18]$, whereas one study did not find such an association among homeless individuals [21].

\subsection{Psychosocial Factors}

In total, $n=$ one study examined the longitudinal association between psychosocial factors and HCU [19]. More precisely, this study examined the association between general locus of control and HCU. This study showed that while the external locus of control was positively associated with a higher frequency of physician visits $(B=0.00, p<0.05)$, the internal locus of control was not significantly associated with the frequency of physician visits longitudinally [19].

\subsection{Quality Assessment}

The quality assessment for our included studies is given in Table 3. In total, 87.5 to $93.8 \%$ of the criteria were achieved by the included studies. The categories that were commonly not fulfilled were the treatment of missing data (30\% fulfilled) and conducting sensitivity analyses (50\% fulfilled). 
Table 3. Quality assessment of studies included in the systematic review.

\begin{tabular}{|c|c|c|c|c|c|c|c|c|c|c|c|c|c|c|c|c|c|}
\hline $\begin{array}{l}\text { First Author } \\
\text { (year) }\end{array}$ & $\begin{array}{c}\text { Study } \\
\text { Objective }\end{array}$ & $\begin{array}{l}\text { Inclusion } \\
\text { and } \\
\text { Exclusion } \\
\text { Criteria }\end{array}$ & $\begin{array}{c}\mathrm{HCU} \\
\text { Description }\end{array}$ & $\begin{array}{c}\text { Comparison } \\
\text { Group or } \\
\text { Disorder- } \\
\text { Specific } \\
\text { HCU } \\
\end{array}$ & Data Source & Missing Data & Statistics & $\begin{array}{l}\text { Consideration } \\
\text { of } \\
\text { Confounders }\end{array}$ & $\begin{array}{l}\text { Sensitivity } \\
\text { Analysis }\end{array}$ & $\begin{array}{l}\text { Sample Size } \\
\text { (Subgroup) }\end{array}$ & Demographics & $\begin{array}{c}\text { Results } \\
\text { Discussed } \\
\text { with Respect } \\
\text { to Other } \\
\text { Studies } \\
\end{array}$ & $\begin{array}{c}\text { Results } \\
\text { Discussed } \\
\text { Regarding } \\
\text { Generaliz- } \\
\text { ability } \\
\end{array}$ & Limitations & $\begin{array}{c}\text { Conclusion } \\
\text { Supported } \\
\text { by Data }\end{array}$ & $\begin{array}{l}\text { Conflict of } \\
\text { Inter- } \\
\text { est/funders }\end{array}$ & $\begin{array}{l}\text { \% of Criteria } \\
\text { Fulfilled by } \\
\text { Study }\end{array}$ \\
\hline Al Snih (2006) & $\checkmark$ & $\checkmark$ & $\checkmark$ & $\checkmark$ & $\checkmark$ & $\mathrm{x}$ & $\checkmark$ & $\checkmark$ & $\mathrm{x}$ & $\checkmark$ & $\checkmark$ & $\checkmark$ & $\checkmark$ & $\checkmark$ & $\checkmark$ & $\checkmark$ & 87.5 \\
\hline $\begin{array}{l}\text { Clay (2011) } \\
\text { Gabet (2019) }\end{array}$ & s & s & s & s & s & s & $\checkmark$ & s & $\begin{array}{l}x \\
x \\
x\end{array}$ & s & v & s & s & s & s & $s$ & $\begin{array}{l}93.8 \\
938\end{array}$ \\
\hline $\begin{array}{l}\text { Hadwiger } \\
\text { (2019) }\end{array}$ & $\checkmark$ & $\checkmark$ & $\checkmark$ & $\checkmark$ & $\checkmark$ & $\mathrm{x}$ & $\checkmark$ & $\checkmark$ & $\begin{array}{l}x \\
v\end{array}$ & $\checkmark$ & $\checkmark$ & $\checkmark$ & $\checkmark$ & $\checkmark$ & $\checkmark$ & $\begin{array}{r}v \\
v\end{array}$ & 93.8 \\
\hline Hajek (2017) & $\checkmark$ & $\checkmark$ & $\checkmark$ & $\checkmark$ & $\checkmark$ & $\mathrm{x}$ & $\checkmark$ & s & $\checkmark$ & $\checkmark$ & $\checkmark$ & s & $\checkmark$ & $\checkmark$ & $\checkmark$ & s & 93.8 \\
\hline $\begin{array}{l}\text { Hajek (2017b) }\end{array}$ & $\checkmark$ & $\checkmark$ & $\checkmark$ & $\checkmark$ & $\checkmark$ & $\mathrm{x}$ & $\checkmark$ & $\checkmark$ & $\checkmark$ & $\checkmark$ & $\checkmark$ & $\checkmark$ & $\checkmark$ & $\checkmark$ & $\checkmark$ & $\checkmark$ & 93.8 \\
\hline $\begin{array}{l}\text { Hajek (2018) } \\
\text { Haiak (2020) }\end{array}$ & s & s & s & $\checkmark$ & $r$ & $\begin{array}{l}x \\
x\end{array}$ & $y$ & $\checkmark$ & $\checkmark$ & $\checkmark$ & $\checkmark$ & $\checkmark$ & $\checkmark$ & $\checkmark$ & s & $\checkmark$ & 93.8 \\
\hline $\begin{array}{l}\text { Hajek (2020) } \\
\text { Kim (2016) }\end{array}$ & $\begin{array}{l}v \\
\text { s }\end{array}$ & s & $\begin{array}{l}v \\
s\end{array}$ & s & s & $\begin{array}{l}x \\
x\end{array}$ & $\checkmark$ & s & v & s & s & $\checkmark$ & s & s & $s$ & $s$ & $\begin{array}{l}93.8 \\
875\end{array}$ \\
\hline $\begin{array}{l}\operatorname{Kim}(2016) \\
\text { Stein }(2000)\end{array}$ & $\checkmark$ & $\checkmark$ & $\checkmark$ & $\checkmark$ & $\checkmark$ & $\checkmark$ & $\checkmark$ & v & $\begin{array}{l}x \\
x\end{array}$ & $\checkmark$ & $\checkmark$ & $\checkmark$ & $\checkmark$ & $\checkmark$ & $\checkmark$ & $\checkmark$ & $\begin{array}{l}87.5 \\
93.8\end{array}$ \\
\hline
\end{tabular}

Notes: $\mathrm{x}=$ not fulfilled; $\checkmark$ = fulfilled. 


\section{Discussion}

The aim of this systematic review was to give an overview of longitudinal observational studies investigating the determinants of healthcare use explicitly using the Andersen model. This knowledge adds to our current understanding of the factors associated with HCU (mainly based on cross-sectional studies). These cross-sectional studies showed, in general, mixed evidence regarding the associations between predisposing characteristics, enabling resources and HCU [5]. Furthermore, cross-sectional studies mainly found an association between higher needs and higher HCU [5].

With regard to the association between predisposing characteristics and $\mathrm{HCU}$, findings were rather mixed or inconclusive. More precisely, the findings were mixed regarding the association between age and HCU (also depending on the model specification). Furthermore, most of the studies did not identify an association between marital status as well as education and HCU. Moreover, there was inconclusive evidence regarding the association between sex, employment status as well as race and HCU. Due to the limited knowledge (mainly based on data taken from Germany or the United States), much more research based on longitudinal data is required to clarify whether the aforementioned predisposing characteristics are important for HCU in other regions.

With regard to the association between enabling resources and HCU, none of the studies found an association between income and HCU. However, it should be noted that all of the studies used data from Germany (and one study used data from South Korea). Thus, future research in other regions (e.g., United States) is urgently required since the German healthcare system (where enabling resources generally do not drive HCU [16]) may heavily contribute to these results.

Since only three studies compared very different groups of health-insured individuals (Germany or United States), future longitudinal studies in this area are required. Moreover, there is mixed evidence regarding the association between social support/social network and HCU. A positive association between these factors may be explained by the fact that the social network urges an individual to check their illness symptoms and can help with transportation.

With regard to the association between need factors and HCU, there was clear evidence for a positive association between these factors (i.e., higher needs are associated with higher $\mathrm{HCU}$ ), particularly between chronic conditions as well as self-rated health and HCU. This is very plausible since an increased need reflects illness symptoms that can be checked by consulting a physician and has been shown by numerous cross-sectional studies [5]. Future longitudinal studies in this area are required to clarify the association between the onset of single diseases and HCU as well as between different multimorbidity patterns and HCU.

With regard to the association between psychosocial factors and HCU, only one study examined this association. This study showed an association between an external locus of control and increased HCU among the general adult population in Germany. Drawing general conclusions from it is, thus, difficult. As some cross-sectional studies showed associations between psychosocial factors as well as personality-related factors and HCU, future longitudinal studies are required to clarify the association between these factors.

The study quality only slightly varied between the studies and was generally high. It is likely that the high quality of the included studies can be explained by the publication date (i.e., seven out of the ten studies were published in the past five years). The most common shortcomings are that robustness checks (i.e., sensitivity analyses) were not conducted. However, conducting such checks is required to ensure that the study findings did not depend, e.g., on the model specification (e.g., which health-related factors are included) or the analytical approach (e.g., panel regression models vs. cross-sectional regression models) used. Consequently, such checks are recommended by current guidelines [23]. Moreover, most of the studies did not describe how they dealt with missing data. Hence, future research could tackle this issue, for example, by using a full-information maximum likelihood approach [24] since such approaches can produce more accurate findings [25]. 
The comparability of the included studies is somewhat restricted. While the majority of the studies used large, mostly representative samples [13,15-20], two studies used data from homeless individuals that are difficult to generalize [14,21]. Moreover, the studies differ in the time horizon. It should also be acknowledged that several of the studies included in our review used specific regression models for dealing with longitudinal data (which is important to receive consistent estimates [22]) [13,15-19], whereas some studies did not use such analytical approaches and are, therefore, prone to bias [12,13,20,21]. Moreover, all the studies included in our review only used self-reported $\mathrm{HCU}$, which is prone to some recall bias [26]. If data are available, claim data should be linked to survey data. The existing studies used rather 'classic' factors included in the Andersen model such as age or chronic conditions. Future research regarding the association between psychosocial factors and HCU is, therefore, required. For example, factors such as loneliness, conscientiousness or neuroticism may moderate the association between need factors and HCU. Such factors could also be integrated in a revised version of the Andersen model, as recently suggested [2].

Furthermore, restrictions were not applied regarding the time and location of the studies. The location of the studies may introduce some heterogeneity in our findings, since the healthcare systems often differ between the countries. Moreover, as outlined above, eight of the ten studies included in our systematic review were published in the past ten years, whereas the two remaining studies were published in the 2000s. This may be explained by the increased availability of longitudinal secondary data. We assume that far more longitudinal studies on this topic will be published in the next few years.

Some strengths and limitations of our systematic review are worth highlighting. This is the first systematic review examining the determinants of $\mathrm{HCU}$ based on the Andersen model exclusively including longitudinal studies. This focus may ascertain a sufficient quality of the studies and may assist in making more valid conclusions. For example, by exploiting the longitudinal data structure, the problem of unobserved heterogeneity can be reduced [27], which is a main advantage in comparison to cross-sectional data. Additionally, using longitudinal data can assist in clarifying the directionality [27]. In particular, the included studies from Germany used such panel regression models and can, therefore, reduce the problem of unobserved heterogeneity. A quality assessment was performed. Two reviewers conducted important steps in this review. Due to study heterogeneity, a meta-analysis could not be conducted. While the restriction to peer-reviewed articles may exclude potentially suitable findings (e.g., grey literature), it ascertains a certain quality. Moreover, since we restricted our search to two languages, potentially suitable studies published in other languages may not be determined.

The Andersen model was initially developed in the 1960s. It was updated and refined over time. Most frequently, the 1995 version of the Andersen model was used in the included studies. However, for example, one study included in our systematic review explicitly focused on homeless individuals and, therefore, used the Gelberg-Andersen Behavioral Model for Vulnerable Populations [28] as a theoretical background. Most of the included studies used secondary data. Therefore, they were frequently restricted in the independent variables they could select from. The use of secondary data and the use of older versions may be reasons why the included studies often focused on similar variables (e.g., age, sex, income, or health-related factors). As also noted above, future studies should also look at the neglected factors of the Andersen model, e.g., financing at the contextual level such as available resources in the community for health services (e.g., rate of health insurance coverage or health care expenditures) or organizational factors such as physician density or office hours.

\section{Conclusions}

This systematic review adds to our current understanding of the factors associated with HCU (mainly based on cross-sectional studies). Similarly to previous cross-sectional studies [5], it showed mixed evidence with regard to the association between predisposing 
characteristics, enabling resources and HCU longitudinally. In contrast, need factors (in particular, self-rated health and chronic conditions) were almost consistently associated with HCU, which confirmed and extended the cross-sectional positive associations between need factors and HCU [5]. This knowledge may assist in managing HCU. Since most of the studies were conducted in North America or Europe, future longitudinal studies from other regions are urgently required.

Author Contributions: The study concept was developed by A.H., B.K. and H.-H.K. The manuscript was drafted by A.H. and critically revised by B.K. and H.-H.K. The search strategy was developed by A.H. and H.-H.K. Study selection, data extraction and quality assessment were performed by A.H. and B.K., with H.-H.K. as a third party in case of disagreements. All authors have read and agreed to the published version of the manuscript.

Funding: This research received no external funding.

Institutional Review Board Statement: Not applicable.

Informed Consent Statement: Not applicable.

Data Availability Statement: Not applicable.

Conflicts of Interest: The authors declare no conflict of interest.

\section{References}

1. Andersen, R.M. Revisiting the Behavioral Model and Access to Medical Care: Does It Matter? J. Health Soc. Behav. 1995, 36, 1-10. [CrossRef]

2. Hajek, A.; König, H.-H. Beyond symptoms: Why do patients see the doctor? BJGP Open 2020, 4, bjgpopen20x101088. [CrossRef] [PubMed]

3. Agyemang-Duah, W.; Peprah, C.; Arthur-Holmes, F. Predictors of healthcare utilisation among poor older people under the livelihood empowerment against poverty programme in the Atwima Nwabiagya District of Ghana. BMC Geriatr. 2020, 20, 79. [CrossRef] [PubMed]

4. Madyaningrum, E.; Chuang, Y.-C.; Chuang, K.-Y. Factors associated with the use of outpatient services among the elderly in Indonesia. BMC Health Serv. Res. 2018, 18, 707. [CrossRef] [PubMed]

5. Babitsch, B.; Gohl, D.; Von Lengerke, T. Re-revisiting Andersen's Behavioral Model of Health Services Use: A systematic review of studies from 1998-2011. GMS Psycho-Soc.-Med. 2012, 9. [CrossRef]

6. Newall, N.; McArthur, J.; Menec, V.H. A longitudinal examination of social participation, loneliness, and use of physician and hospital services. J. Aging Health 2015, 27, 500-518. [CrossRef]

7. Moher, D.; Liberati, A.; Tetzlaff, J.; Altman, D.G.; Group, P. Preferred reporting items for systematic reviews and meta-analyses: The PRISMA statement. PLoS Med. 2009, 6, e1000097. [CrossRef]

8. Hajek, A.; Kretzler, B.; König, H.-H. Determinants of healthcare use based on the Andersen model: A study protocol for a systematic review of longitudinal studies. BMJ Open 2021, 11, e044435. [CrossRef]

9. Stuhldreher, N.; Konnopka, A.; Wild, B.; Herzog, W.; Zipfel, S.; Löwe, B.; König, H.H. Cost-of-illness studies and cost-effectiveness analyses in eating disorders: A systematic review. Int. J. Eat. Disord. 2012, 45, 476-491. [CrossRef]

10. Hohls, J.K.; Koenig, H.-H.; Raynik, Y.I.; Hajek, A. A systematic review of the association of anxiety with health care utilization and costs in people aged 65 years and older. J. Affect. Disord. 2018, 232, 163-176. [CrossRef]

11. Hajek, A.; Kretzler, B.; König, H.-H. Determinants of frequent attendance in primary care. A systematic review of longitudinal studies. Front. Med. 2021, 8, 595674. [CrossRef]

12. Al Snih, S.; Markides, K.S.; Ray, L.A.; Freeman, J.L.; Ostir, G.V.; Goodwin, J.S. Predictors of healthcare utilization among older Mexican Americans. Ethn. Dis. 2006, 16, 640-646. [PubMed]

13. Clay, O.J.; Roth, D.L.; Safford, M.M.; Sawyer, P.L.; Allman, R.M. Predictors of overnight hospital admission in older African American and Caucasian Medicare beneficiaries. J. Gerontol. Ser. A Biomed. Sci. Med Sci. 2011, 66, 910-916. [CrossRef] [PubMed]

14. Gabet, M.; Grenier, G.; Cao, Z.; Fleury, M.-J. Predictors of emergency department use among individuals with current or previous experience of homelessness. Int. J. Environ. Res. Public health 2019, 16, 4965. [CrossRef] [PubMed]

15. Hadwiger, M.; König, H.-H.; Hajek, A. Determinants of frequent attendance of outpatient physicians: A longitudinal analysis using the German socio-economic panel (GSOEP). Int. J. Environ. Res. Public Health 2019, 16, 1553. [CrossRef] [PubMed]

16. Hajek, A.; Bock, J.-O.; König, H.-H. Which factors affect health care use among older Germans? Results of the German ageing survey. BMC Health Serv. Res. 2017, 17, 30. [CrossRef] [PubMed]

17. Hajek, A.; Brettschneider, C.; Eisele, M.; Kaduszkiewicz, H.; Mamone, S.; Wiese, B.; Weyerer, S.; Werle, J.; Fuchs, A.; Pentzek, M.; et al. Correlates of hospitalization among the oldest old: Results of the AgeCoDe-AgeQualiDe prospective cohort study. Aging Clin. Exp. Res. 2020, 32, 1295-1301. [CrossRef] 
18. Hajek, A.; Brettschneider, C.; van den Bussche, H.; Kaduszkiewicz, H.; Oey, A.; Wiese, B.; Weyerer, S.; Werle, J.; Fuchs, A.; Pentzek, M.; et al. Longitudinal Analysis of Outpatient Physician Visits in the Oldest Old: Results of the AgeQualiDe Prospective Cohort Study. J. Nutr. Health Aging 2018, 22, 689-694. [CrossRef]

19. Hajek, A.; König, H.H. Locus of control and frequency of physician visits: Results of a population-based longitudinal study in Germany. Br. J. Health Psychol. 2017, 22, 414-428. [CrossRef]

20. Kim, H.-K.; Lee, M. Factors associated with health services utilization between the years 2010 and 2012 in Korea: Using Andersen's behavioral model. Osong Public Health Res. Perspect. 2016, 7, 18-25. [CrossRef]

21. Stein, J.A.; Andersen, R.M.; Koegel, P.; Gelberg, L. Predicting health services utilization among homeless adults: A prospective analysis. J. Health Care Poor Underserved 2000, 11, 212-230. [CrossRef] [PubMed]

22. Cameron, A.C.; Trivedi, P.K. Microeconometrics: Methods and Applications; Cambridge University Press: Cambridge, UK, 2005.

23. Von Elm, E.; Altman, D.G.; Egger, M.; Pocock, S.J.; Gøtzsche, P.C.; Vandenbroucke, J.P.; Initiative, S. The Strengthening the Reporting of Observational Studies in Epidemiology (STROBE) Statement: Guidelines for reporting observational studies. Int. J. Surg. 2014, 12, 1495-1499. [CrossRef] [PubMed]

24. Von Hippel, P.T. New confidence intervals and bias comparisons show that maximum likelihood can beat multiple imputation in small samples. Struct. Equ. Modeling Multidiscip. J. 2016, 23, 422-437. [CrossRef]

25. Allison, P.D. Missing Data; Sage: Thousand Oaks, CA, USA, 2001.

26. Bhandari, A.; Wagner, T. Self-reported utilization of health care services: Improving measurement and accuracy. Med Care Res. Rev. 2006, 63, 217-235. [CrossRef] [PubMed]

27. Brüderl, J.; Ludwig, V. Fixed-effects panel regression. In The SAGE Handbook of Regression Analysis and Causal Inference; Wolf, C., Ed.; SAGE: Los Angeles, CA, USA, 2015; pp. 327-357.

28. Gelberg, L.; Andersen, R.M.; Leake, B.D. The Behavioral Model for Vulnerable Populations: Application to medical care use and outcomes for homeless people. Health Serv. Res. 2000, 34, 1273. 